\title{
DETERMINATION OF DROUGHT RESISTANCE OF SOME DURUM AND BREAD WHEAT CULTIVARS WITH AGRICULTURAL AND PHYSICOCHEMICAL PARAMETERS
}

\author{
ALP, A. ${ }^{1 *}-$ ASLAN, A. ${ }^{1}-$ KoCA, Y. K. ${ }^{2}$ \\ ${ }^{I}$ Dicle University Faculty of Agriculture, Department of Field Crops, Diyarbakır, Turkey \\ ${ }^{2}$ Dicle University Faculty of Agriculture, Department of Soil Science, Diyarbakır, Turkey \\ *Corresponding author \\ e-mail:aydinalp21@hotmail.com
}

(Received $15^{\text {th }}$ Nov 2018; accepted $14^{\text {th }}$ Feb 2019)

\begin{abstract}
The aim of this study is to demonstrate the effects of water shortage, which may occur in different periods, on wheat grain yield and quality. One of the most important factors limiting wheat yield in the Southeastern Anatolia Region of Turkey is drought, which is caused by inadequate precipitation and irregular distribution over the year. Four different bread and durum wheat cultivars (Sarıçanak-98, Firat-93, Pehlivan, Ceyhan-99), which are widely cultivated in the region, were used as the material of the study. The experiment was carried out with 3 replications, according to the random blocks design. The research was carried out under greenhouse conditions. The effects of four different drought conditions on the wheat's development, yield and mineral content were investigated under irrigation (K0), early drought $(\mathrm{K} 1)$, late drought (K2) and full drought (K3). According to the results, a $9.12 \%$ loss in chlorophyll content was observed under irrigated conditions (K0). $21.68 \%$ leaf area, $28.98 \%$ plant green area, and $52.09 \%$ plant height declines were recorded. The amount of potassium $(\mathrm{K})$ was found to change between $2.86 \mathrm{mg}(\mathrm{K} 3)$ and $34.77 \mathrm{mg}(\mathrm{K} 2)$, while the amount of calcium (Ca) changed between $0.67 \mathrm{mg}(\mathrm{K} 3)$ and $33.23 \mathrm{mg}(\mathrm{K} 3)$ and the amount of sodium (Na) changed between $0.20 \mathrm{mg}(\mathrm{K} 1)$ and $27.05 \mathrm{mg}(\mathrm{K} 0)$ in the root and stem of plants.
\end{abstract}

Keywords: wheat, drought, drought applications, drought parameters, chlorophyll content, agricultural and biochemical characteristics

\section{Introduction}

Most of the agricultural areas in the world are affected by different stress factors. Drought stress affects these areas the most at a rate of $26 \%$, mineral substance stress ranks the second, affecting them at a rate of $20 \%$, and cold and frost stress rank the third with $15 \%$. Aside from these, $29 \%$ are affected by other stress factors and $10 \%$ are not under any stress (Kalefetoglu and Ekmekçi, 2005). In areas where there is drought risk, the decrease in the water amount available in the soil primarily leads to a reduction in the water potential of the plant. It is well-known that turgor pressure drops, stomas are closed, and leaf development and photosynthesis is decreased in the following stages (Monti, 1986).

It was reported that $55 \%$ of the wheat cultivation areas throughout the world are affected by drought stress periodically (Richards et al., 2010). The wheat yield in affected areas less than between $50 \%$ to $90 \%$ of yield potential of irrigable conditions (Reynolds et al., 1999). It would be useful to develop new and multidisciplinary methods together with classical cultivation methods used for the development of drought-tolerant wheat cultivars.

In Turkey, in the development studies for the drought-tolerant wheat cultivars, generally the "earliness" feature of the plants was used. The height of the plant and leaf 
width are used as selection criteria. In later generations, drought-resistant cultivars are cultivated as a result of the yield level and "decisiveness". The severity of drought is a serious danger for the Southeastern Anatolian Region of Turkey. The reason of the danger varies depending on years, and it is not known how long the drought stress will last during the development of the wheat and how long its duration will be. In this case, the feature of "earliness" is not adequate for the yield in the conditions of the region, and genetic and some physiological properties are important in determining the resistance to drought. For this reason, it is desired that the cultivars that are developed have a yield potential which are capable of making use of the formation of optimum conditions meanwhile maintaining the yield at a certain rate compared to the sensitive plants when exposed to drought stress.

The yield of the cultivars that are not sensitive to drought stress stays the same even in the most suitable development conditions. The lack of photosynthesis area is shown as the reason for this. Due to this fact, in order to increase the yield, it is necessary to have high photosynthesis capacity as well as physiological durability. The efforts spent on developing a strong wheat variety require physiological tests which are inexpensive, simple, and repeatable and which may be considered as selection criteria with morphological parameters.

In Turkey, wheat plant is cultivated in conditions based on precipitation at a rate of $80 \%$. The total rainfall is not adequate in dry agricultural areas where most of the total rain falls between November and April, and because of the irregular distribution, dry periods in different development stages cause the yield to be reduced.

The purpose of this research is to determine the endurance of bread and durum wheat cultivars produced in the Southeastern Anatolian Region of Turkey by using agricultural, quality and physicochemical parameters under different ecological conditions, which may be seen in different plant growth periods.

\section{Materials and methods}

This study was conducted in Dicle University, Agricultural Faculty, Field Plants Department, Medicinal and Aromatic Plants, Open Green House conditions in 2015-16 and 2016-17 cultivation periods. The greenhouse in which the study was performed was open in both sides and the top part was covered; and did not have any limiting factors that hindered air, light and wind. Two bread wheat (Pehlivan, Ceyhan-99) and 2 durum wheat cultivars (Sarıçanak-98, Fırat-93), which are cultivated widely in the region were used in the study as the study material. Firat-93 and Pehlivan control cultivars have been produced in the region for many years, and have proven themselves to the drought and other negative conditions of the region. Ceyhan-99 and Sarıçanak-98 varieties are cultivated in large areas in the region. The cultivation of wheat in the province of Diyarbakır is made entirely in autumn. All cultivars used as materials were cultivated in autumn. Pehlivan is a kind of biological winter. The study was carried out according to the experimental design of random blocks with 3 replications.

In the Southeastern Anatolian Region of Turkey, precipitation is seldom in summer season. The relative humidity in the air is also quite low. The annual precipitation average of the region has been $485.7 \mathrm{~mm}$ and the relative humidity has been around $58 \%$ for many years. The trial soils in which the study was carried out is clayey and loamy; and the salt level is low. It is rich in potassium $(0.42 \%)$, slightly alkaline ( $\mathrm{pH} 7.77)$, normal limy $(7.81 \% \mathrm{CaCO} 3)$ and poor in organic matter $(1.67 \%)$. 
The pots which were used in the study were 0.085 square meters each (Diameter: $34 \mathrm{~cm}$, height: $60 \mathrm{~cm}$ ) and had $18 \mathrm{~kg}$ soil volume. The seeding process was done as 12 seeds per pot. After the seeding was done in mid-November as 450 seeds $/ \mathrm{m}^{2}$, the first irrigation for all of the pots was done for germination. In October, the pots were added $20 \mathrm{~kg}$ (DAP 18:46) and urea (46\% N) as top-fertilizer.

Drought applications as follows: Fully Irrigated Conditions (K0): The plants were irrigated from the time of planting to maturity, when about $40 \%$ of the available water in the soil was consumed. Early Drought (K1): The plants were not irrigated and irrigation was avoided from the time when the second node appeared on the plant to the beginning of the milking stage. Late Drought (K2): The plants were grown in irrigated conditions until the beginning of the milking stage. Irrigation was avoided from the beginning of milking stage to the harvesting period and irrigation was not carried out. Full Drought (K3): Irrigation was avoided from the 2nd node on the plant base until the harvest time. No irrigation was made. Drought applications were determined based on "Feekes" development period scala values by using the gravimetric method (Zadoks et al., 1974; Cook and Veseth, 1991).

In this research, vegetative characters such as leaf area and index, plant green area, chlorophyll content, plant height, generative characters such as number of grain, grain weight and grain yield and some drought parameters were tried. Leaf area consists only of leaf (lamina) and leaf sheath (vagina), the plant green area consists of the sum of the fields of spike, leaf organs, node and internodes of stem.

In this study, the endurance to drought parameters like the yield, quality and mineral substance contents, Potassium, Calcium and Sodium Concentration in green parts and roots $(\mathrm{mg} / \mathrm{kg}$ dry weight). Fresh leaf samples were washed with $0.1 \% \mathrm{HCl}$ and in pure water and then dried at $70^{\circ} \mathrm{C}$ for 48 hours. 200 milligrams of these samples were incinerated for 5 hours at $550^{\circ} \mathrm{C}$ in an ash furnace. The ash obtained was dissolved in $3.3 \% \mathrm{HCl}$ and filtered using blue tape filter paper (Bremner, 1965). In the obtained filtrate, $\mathrm{K}, \mathrm{Ca}, \mathrm{Na}$ concentrations were determined by atomic absorption device (Atiunicam 929) in solution.

The chlorophyll content was measured in the 3rd and 4th leaves of plants by the SPAD meter device. the readings were made with the Minolta brand SPAD meter and, the chlorophyll content units were given as SPAD value.

With the data that were obtained as a result of the study, and by using the JUMP 7.0 Statistics Program, variance analysis was made, and the differences between the average scores were evaluated with the LSD Test.

\section{Results and discussion}

In this study, in terms of wheat cultivars, it was found that the highest leaf area average was in Ceyhan-99 variety with $28.70 \mathrm{~cm}^{2}$; and the lowest leaf area average score was in Sarıçanak-98 variety with $25.18 \mathrm{~cm}^{2}$. The highest leaf area in irrigated conditions (K0) was $31.36 \mathrm{~cm}^{2}$, followed respectively by late drought application (K2) with a decrease of $13.23 \%$; full drought application (K3) with a decrease of $16.77 \%$; and early drought application with a decrease of $21.68 \%$ (Table 1).

In terms of the cultivars, the highest plant green area was determined in Pehlivan with $128.16 \mathrm{~cm}^{2}$ and the lowest green area average was in Sarıçanak-98 with $110.85 \mathrm{~cm}^{2}$. In terms of drought applications, the highest green area value was determined in irrigated conditions (K0: $138.7 \mathrm{~cm}^{2}$ ), followed respectively by late 
drought application (K2) with a decrease of 5.54\%; early drought application (K1) with a decrease of $16.46 \%$; full drought applications (K3) with a decrease of $28.98 \%$ (Table 1).

Table 1. The average values of Leaf Area $\left(\mathrm{cm}^{2}\right)$, plant green area $\left(\mathrm{cm}^{2}\right)$ and the formed groups according to the LSD (least significant difference) test

\begin{tabular}{l|c|c|c|c|c|c|c|c|c|c}
\hline & \multicolumn{5}{|c|}{ Leaf Area $\left(\mathbf{c m}^{\mathbf{2}}\right)$} & \multicolumn{5}{c}{ Plant Green Area $\left(\mathbf{c m}^{\mathbf{2}}\right)$} \\
\hline Cultivars & K0 & K1 & K2 & K3 & Average & K0 & K1 & K2 & K3 & Average \\
\hline Ceyhan-99 & $30.65 \mathrm{ab}$ & $27.01 \mathrm{cde}$ & $31.16 \mathrm{ab}$ & $25.99 \mathrm{def}$ & 28.70 & $125.6 \mathrm{~b}-\mathrm{e}$ & $107.9 \mathrm{e}-\mathrm{g}$ & $157.6 \mathrm{a}$ & $96.9 \mathrm{~g}$ & $122.0 \mathrm{~A}$ \\
Pehlivan & $34.23 \mathrm{a}$ & $25.26 \mathrm{def}$ & $23.80 \mathrm{ef}$ & $25.54 \mathrm{def}$ & 27.21 & $139.6 \mathrm{a}-\mathrm{c}$ & $142.5 \mathrm{ab}$ & $134.5 \mathrm{bc}$ & $96.0 \mathrm{~g}$ & $128.2 \mathrm{~A}$ \\
Furat-93 & $30.55 \mathrm{bc}$ & $26.07 \mathrm{def}$ & $30.63 \mathrm{abc}$ & $25.33 \mathrm{def}$ & 28.15 & $133.4 \mathrm{bc}$ & $109.0 \mathrm{~d}-\mathrm{g}$ & $122.5 \mathrm{c}-\mathrm{f}$ & $127.8 \mathrm{~b}-\mathrm{d}$ & $123.2 \mathrm{~A}$ \\
Sarı̧canak-98 & $30.01 \mathrm{bc}$ & $19.88 \mathrm{~g}$ & $23.26 \mathrm{fg}$ & $27.56 \mathrm{bcd}$ & 25.18 & $156.3 \mathrm{a}$ & $104.2 \mathrm{fg}$ & $109.6 \mathrm{~d}-\mathrm{g}$ & $73.38 \mathrm{~h}$ & $110.8 \mathrm{~B}$ \\
\hline Average & $31.36 \mathrm{~A}$ & $24.56 \mathrm{C}$ & $27.21 \mathrm{~B}$ & $26.10 \mathrm{BC}$ & & $138.7 \mathrm{~A}$ & $115.9 \mathrm{~B}$ & $131.0 \mathrm{~A}$ & $98.5 \mathrm{C}$ & \\
\hline LSD (C) & ÖD & & & & & $7.14^{* *}$ & & & & \\
LSD (D) & $1.82^{* *}$ & & & & & $9.45^{* *}$ & & & & \\
LSD (C)x(D) & $3.63^{* *}$ & & & & & $18.89^{* *}$ & & & & \\
\hline
\end{tabular}

It was determined that the highest leaf area index average was in Pehlivan with 2.06 and the lowest leaf area index average was in Sarıçanak-98 with 1.57. In terms of drought applications, it was determined the highest leaf area index value was 3.05 in irrigated conditions, followed respectively by late drought application (2.15), early drought application (1.32) and full drought applications (0.88) (Table 2).

Table 2. The average values of Leaf Area Index, Chlorophyll Content (SPAD) and the formed groups according to the LSD (least significant difference) test

\begin{tabular}{l|c|c|c|c|c|c|c|c|c|c}
\hline & \multicolumn{5}{|c|}{ Leaf Area index } & \multicolumn{5}{c}{ Chlorophyll Content (SPAD) } \\
\hline Cultivars & K0 & K1 & K2 & K3 & Average & K0 & K1 & K2 & K3 & Average \\
\hline Ceyhan-99 & 3.06 & 1.65 & 2.51 & 0.90 & $2.03 \mathrm{~A}$ & 62.40 & 52.69 & 59.60 & 52.27 & $56.74 \mathrm{C}$ \\
Pehlivan & 3.73 & 1.76 & 2.04 & 0.71 & $2.06 \mathrm{~A}$ & 60.80 & 56.49 & 57.41 & 63.91 & $59.65 \mathrm{~B}$ \\
Firat-93 & 2.67 & 0.94 & 2.43 & 0.94 & $1.75 \mathrm{AB}$ & 61.25 & 53.10 & 62.79 & 67.08 & $61.05 \mathrm{~A}$ \\
Sarıçanak-98 & 2.75 & 0.94 & 1.61 & 0.98 & $1.57 \mathrm{~B}$ & 59.94 & 59.84 & 60.61 & 60.27 & $60.16 \mathrm{~B}$ \\
\hline Average & $3.05 \mathrm{~A}$ & $1.32 \mathrm{C}$ & $2.15 \mathrm{~B}$ & $0.88 \mathrm{D}$ & & $61.10 \mathrm{~A}$ & $60.88 \mathrm{AB}$ & $60.10 \mathrm{~B}$ & $55.53 \mathrm{C}$ & \\
\hline LSD (C) & 0.03 & & & & & $0.67^{* *}$ & & & & \\
LSD (D) & 0.03 & & & & & $0.85^{* *}$ & & & & \\
LSD (C)x(D) & ÖD & & & & & 1.7 & & & & \\
\hline
\end{tabular}

In terms of average values of the cultivars, it was determined that the highest chlorophyll content was in Firat-93 with 61.05 SPAD and the lowest chlorophyll content was in Ceyhan-99 with 56.74 SPAD. In terms of drought applications, it was determined that the highest chlorophyll content value was 61.10 in irrigated conditions (K0), followed respectively by early drought application (K1: 60.88), late drought application (K2: 60.10) and full drought applications (K3: 55.53 SPAD) (Table 2).

In the present study, it was determined that leaf area, plant green area and chlorophyll content were affected by drought applications. The highest values obtained from the irrigated conditions showed that especially the early drought applications were 
affected more at a rate of approximately 50\%. In fact, plants reduce the transpiration area to decrease water loss to a minimum level with their decreasing leaf surface area in stress conditions. Chlorophyll content is affected by drought stress and is decreased at a significant level when compared with normal irrigated conditions. Chlorophyll decomposition is increased towards the end of the development period due to drought stress (Aghanejad et al., 2015).

It was determined that the highest plant height average was $56.08 \mathrm{~cm}$ in Sarıçanak-98 and the lowest plant height average was $50.61 \mathrm{~cm}$ in Pehlivan. In terms of drought applications, it was determined that the highest plant height value in irrigated conditions (K0) was $69.93 \mathrm{~cm}$, followed respectively by early drought application (K1) with a $3.07 \%$ decrease; late drought application (K2) with a $39.11 \%$ decrease; and full drought applications (K3) with a 52.09\% decrease (Table 3).

The highest number of spike was determined in Pehlivan as 714 pieces $/ \mathrm{m}^{2}$ and the lowest number of ears value was determined in Firat-93 variety as 611 pieces $/ \mathrm{m}^{2}$. In terms of drought applications, the highest number of ears in square meter in irrigated conditions was 967 pieces, followed respectively by late drought application (K2: 813), early drought application (K1: 506) and full drought applications (K3: 343) (Table 3).

Table 3. The average values of plant height $(\mathrm{cm})$, the number of spike and the formed groups according to the LSD (least significant difference) test

\begin{tabular}{l|c|c|c|c|c|c|c|c|c|c}
\hline & \multicolumn{5}{|c|}{ Plant Height $(\mathbf{c m})$} & \multicolumn{5}{c}{ The Number of Spike (pieces / $\left.\mathbf{m}^{\mathbf{2}}\right)$} \\
\hline Cultivars & K0 & K1 & K2 & K3 & Average & K0 & K1 & K2 & K3 & Average \\
\hline Ceyhan-99 & 70.93 & 50.53 & 62.80 & 32.33 & $54.15 \mathrm{~B}$ & 984 & 596 & 839 & 333 & $688 \mathrm{~B}$ \\
Pehlivan & 66.93 & 35.66 & 66.06 & 33.80 & $50.61 \mathrm{D}$ & 1050 & 658 & 847 & 301 & $714 \mathrm{~A}$ \\
Firat-93 & 71.20 & 33.20 & 73.60 & 33.80 & $52.95 \mathrm{C}$ & 914 & 368 & 792 & 372 & $611 \mathrm{C}$ \\
Sarıçanak-98 & 70.66 & 50.93 & 68.66 & 34.06 & $56.08 \mathrm{~A}$ & 921 & 404 & 776 & 364 & $616 \mathrm{C}$ \\
\hline Average & $69.93 \mathrm{~A}$ & $67.78 \mathrm{~B}$ & $42.58 \mathrm{C}$ & $33.50 \mathrm{D}$ & & $967 \mathrm{~A}$ & $506 \mathrm{C}$ & $813 \mathrm{~B}$ & $343 \mathrm{D}$ & \\
\hline LSD (C) & $0.79^{* *}$ & & & & & ÖD & & & & \\
LSD (D) & $1.85^{* *}$ & & & & & 9.26 & & & & \\
LSD (C)x(D) & 3.69 & & & & & ÖD & & & & \\
\hline
\end{tabular}

The highest fertile stem ratio was determined in Ceyhan-99 with $68.89 \%$ and the lowest fertile stem ratio average was determined in Firat-93 with $45.16 \%$. In terms of drought applications, the highest fertile stem ratio in irrigated conditions was found as $93.72 \%$, followed respectively by late drought application (K2) and early drought application (K1). In full drought applications (K3), the fertile stem ratio was determined to be $0 \%$ (Table 4).

In the present study, when the average values of the cultivars were examined it was determined that the highest thousand grain weight was determined in Pehlivan with $26.72 \mathrm{~g}$ and the lowest thousand grain weight was determined in Firat-93 with $19.21 \mathrm{~g}$; and in terms of drought applications, it was determined that the average value varied between $19.49 \mathrm{~g}$ and $42.71 \mathrm{~g}$. The highest thousand grain weight value in irrigated conditions (K0) was determined as $42.71 \mathrm{~g}$ followed respectively by late drought application (K2) with a decrease of $21.33 \%$; and by early drought application (K1) with a decrease of 54.37\%. No grains were obtained in the Full Drought Application (K3) (Table 4). 
Table 4. The average values of fertile stem ratio (\%), the thousand grain weight and the formed groups according to the LSD (least significant difference) test

\begin{tabular}{l|c|c|c|c|c|c|c|c|c|c}
\hline & \multicolumn{5}{|c|}{ Fertile Stem Ratio (\%) } & \multicolumn{5}{c}{ The Thousand Grain Weight (g) } \\
\hline Cultivars & K0 & K1 & K2 & K3 & Average & K0 & K1 & K2 & K3 & Average \\
\hline Ceyhan-99 & 97.57 & 91.44 & 88.54 & - & $68.89 \mathrm{~A}$ & 43.97 & 28.47 & 31.04 & - & $25.87 \mathrm{AB}$ \\
Pehlivan & 99.44 & 92.75 & 64.15 & - & $64.09 \mathrm{~A}$ & 43.69 & 27.84 & 35.33 & - & $26.72 \mathrm{~A}$ \\
Firat-93 & 89.99 & - & 90.64 & - & $45.16 \mathrm{~B}$ & 44.81 & - & 32.01 & - & $19.21 \mathrm{C}$ \\
Sarı̧̧anak-98 & 89.86 & 84.67 & 91.06 & - & $66.40 \mathrm{~A}$ & 38.38 & 21.64 & 36.00 & - & $24.01 \mathrm{~B}$ \\
\hline Average & $93.72 \mathrm{~A}$ & $67.22 \mathrm{C}$ & $83.60 \mathrm{~B}$ & - & & $42.71 \mathrm{~A}$ & $19.49 \mathrm{~B}$ & $33.60 \mathrm{C}$ & - & \\
\hline LSD (C) & $1.01^{* *}$ & & & & & $0.06^{* *}$ & & & & \\
LSD (D) & $1.15^{* *}$ & & & & & $0.05^{* *}$ & & & & \\
LSD (C)x(D) & 2.29 & & & & & 0.1 & & & & \\
\hline
\end{tabular}

It was determined that the highest number of grains in the spike was in Ceyhan-99 with 24.86 and the lowest number of grains in the spike in average was in Frrat-93 variety with 14.01. In terms of drought applications, the highest number of grains in the spike in irrigated conditions (K0) was 35.01, followed respectively by early drought application (K1: 31.52) with a decrease of 9.97\%; and late drought application (K2: 12.67) with a decrease of $63.81 \%$. No grains were obtained in the Full Drought Application (K3) (Table 5).

Table 5. The average values of the number of grain per spike, grain yield $(\mathrm{kg} / \mathrm{ha})$ and the formed groups according to the LSD (least significant difference) test

\begin{tabular}{l|c|c|c|c|c|c|c|c|c|c}
\hline & \multicolumn{5}{|c|}{ The Number of Grain per Spike } & \multicolumn{5}{c}{ Grain Yield (kg/ha) } \\
\hline Cultivars & K0 & K1 & K2 & K3 & Average & K0 & K1 & K2 & K3 & Average \\
\hline Ceyhan-99 & 43.02 & 19.35 & 36.40 & - & $24.86 \mathrm{~A}$ & 5964.7 & 1498.8 & 4765.9 & - & $3057.4 \mathrm{~A}$ \\
Pehlivan & 35.63 & 18.32 & 35.26 & - & $22.48 \mathrm{AB}$ & 5895.3 & 1314.1 & 4657.6 & - & $2966.8 \mathrm{AB}$ \\
Furat-93 & 26.92 & - & 27.73 & - & $14.02 \mathrm{C}$ & 5238.8 & - & 4274.1 & - & $2378.2 \mathrm{C}$ \\
Sarıçanak-98 & 34.49 & 12.32 & 26.68 & - & 18.55 & 5324.7 & 983.5 & 4752.9 & - & $2765.3 \mathrm{~B}$ \\
\hline Average & $35.01 \mathrm{~A}$ & $31.52 \mathrm{~A}$ & $12.67 \mathrm{~B}$ & - & & $5605.9 \mathrm{~A}$ & $949.1 \mathrm{C}$ & $4612.6 \mathrm{~B}$ & - & \\
\hline LSD (C) & $4.10^{* *}$ & & & & & $0.47^{* *}$ & & & & \\
LSD (D) & $3.73^{*}$ & & & & & $0.49^{* *}$ & & & & \\
LSD (C)x(D) & 7.45 & & & & & 0.99 & & & & \\
\hline
\end{tabular}

The highest average grain yield was determined in Ceyhan-99 variety with $3057.4 \mathrm{~kg} / \mathrm{ha}$ and the lowest grain yield average was determined in Firat-93 with $2378.2 \mathrm{~kg} / \mathrm{ha}$; and in terms of drought applications, the average values varied between $949.1 \mathrm{~kg} / \mathrm{ha}$ and $5605.9 \mathrm{~kg} / \mathrm{ha}$. The highest grain yield value in irrigated conditions (K0) was determined as $5605.9 \mathrm{~kg} / \mathrm{ha}$ followed respectively by early drought application (K1) with a decrease of $17.72 \%$; and late drought application (K2) with a decrease of 83.07\%. No grains were obtained in the Full Drought Application (K3) (Table 5). Early drought applications were found to be effective on plant height, especially grain number per spike and indirectly on grain yield. Grain yield was taken but remained quite low.

In terms of drought applications, it was determined that the highest potassium amount in the plant root tissues was in early and late drought applications (K1: 18.71 
and $\mathrm{K} 2: 18.20 \mathrm{mg}$ ), and the lowest potassium amount was $13.09 \mathrm{mg}$ in full irrigated conditions. In the evaluation made in terms of variety-drought applications, the highest Potassium amount was determined in Sarıçanak-98 in the late drought application (K2: $18.23 \mathrm{mg}$ ), and the lowest Potassium amount value was found in Ceyhan-99 variety in late drought application (K2: $5.12 \mathrm{mg}$ ) (Table 6). In terms of the potassium (K) amount in the stem tissues of the wheat plants, when the average values of the cultivars were examined, it was determined that the highest Potassium amount was in Ceyhan-99 variety $(24.47 \mathrm{mg}$ ) and the lowest Potassium amount was in Pehlivan variety (14.94 mg). In terms of drought levels, it was determined that the highest Potassium amount average was found in early drought application (K1: $18.71 \mathrm{mg})$, and the lowest Potassium average was found in irrigated conditions (K0: $13.09 \mathrm{mg}$ ) (Table 6).

Table 6. The average values of potassium amounts in the plant roots and stems

\begin{tabular}{c|c|c|c|c|c|c|c|c|cc}
\hline & \multicolumn{10}{c}{ Potassium (K) } \\
\hline & \multicolumn{2}{|c|}{ K0 } & \multicolumn{2}{c}{ K1 } & \multicolumn{2}{c}{ K2 } & \multicolumn{2}{c}{ K3 } & \multicolumn{3}{c}{ Average } \\
\hline Cultivars & Root & Stem & Root & Stem & Root & Stem & Root & Stem & Root & Stem \\
\hline Ceyhan-99 & 17.34 & 6.53 & 18.46 & 7.34 & 34.77 & 5.12 & 20.17 & 10.02 & 24.47 & 7.25 \\
Pehlivan & 15.81 & 5.86 & 19.74 & 13.54 & 22.22 & 6.62 & 2.86 & 12.53 & 14.94 & 9.64 \\
Firat-93 & 12.92 & 13.07 & 18.38 & 7.92 & 5.26 & 5.29 & 21.55 & 12.49 & 15.06 & 9.69 \\
Sarıçanak-98 & 6.307 & 14.19 & 18.26 & 7.82 & 10.56 & 18.23 & 26.07 & 6.21 & 18.29 & 11.61 \\
\hline Average & 13.09 & 9.91 & 18.71 & 9.16 & 18.20 & 8.82 & 17.66 & 10.31 & & \\
\hline
\end{tabular}

In the examinations on plant roots, it was determined that Firat-93 variety had a value of $16.63 \mathrm{mg}$ in terms of Calcium amount and Ceyhan-99 variety had an average of $6.15 \mathrm{mg}$. In terms of drought levels, the highest Calcium amount was determined in the late drought application (K2: $17.20 \mathrm{mg}$ ), the lowest Calcium average was determined in the full drought application (K3: $7.15 \mathrm{mg}$ ). In terms of variety-drought interaction, it was determined that the highest Calcium amount value was in Pehlivan variety in late drought application (K2: $29.40 \mathrm{mg}$ ), and the lowest Calcium amount value was in Firat-93 variety in full drought application (K3: $0.670 \mathrm{mg}$ ) (Table 7).

Table 7. The average values of Calcium amount in the plant roots and stems

\begin{tabular}{c|c|c|c|c|c|c|c|c|c|c}
\hline \multicolumn{10}{c|}{ K0 } & \multicolumn{2}{c}{ K1 } & \multicolumn{2}{c}{ K2 } & \multicolumn{2}{c}{ K3 } & \multicolumn{3}{c}{ Average } \\
\hline Cultivars & Root & Stem & Root & Stem & Root & Stem & Root & Stem & Root & Stem \\
\hline Ceyhan-99 & 7.00 & 11.76 & 8.02 & 12.10 & 3.45 & 12.25 & 6.15 & 33.23 & 17.33 & 6.15 \\
Pehlivan & 6.66 & 13.84 & 14.29 & 15.66 & 29.40 & 9.52 & 7.92 & 10.20 & 12.30 & 14.57 \\
Firat-93 & 14.07 & 14.91 & 10.53 & 11.85 & 25.30 & 9.62 & 0.67 & 4.61 & 10.24 & 16.63 \\
Sarıçanak-98 & 9.26 & 9.25 & 10.70 & 10.80 & 10.74 & 11.15 & 7.383 & 5.86 & 9.271 & 9.52 \\
\hline Average & 9.25 & 12.44 & 10.88 & 12.61 & 17.20 & 10.63 & 7.15 & 13.47 & & \\
\hline
\end{tabular}

In terms of the Calcium (Ca) amount found in the stem tissues of the wheat plants, when the average values were examined in terms of the average values of the cultivars, it was determined that the highest Calcium amount was in Ceyhan-99 variety (17.33 $\mathrm{mg}$ ) and the lowest Calcium amount was in Sarıçanak-98 variety $(9.27 \mathrm{mg})$. In terms of 
drought levels, it was determined that the highest Calcium amount average was in full drought application (K3: $13.47 \mathrm{mg}$ ), and the lowest Calcium average was in late drought application (K2: $10.63 \mathrm{mg})$ (Table 7).

As a result of the analyses made on the plant root tissues it was found that the highest Sodium amount was in Ceyhan-99 variety $(18.33 \mathrm{mg})$ and the lowest Sodium amount was in Pehlivan variety $(2.22 \mathrm{mg})$. In terms of drought applications, the highest Sodium amount average was determined in irrigated conditions (K0:14.51 mg), and the lowest Sodium average was found in late drought application (K2: $9.10 \mathrm{mg}$ ). In terms of variety-drought interaction, the highest Sodium amount was determined in Ceyhan-99 variety in early drought application (K1: $23.34 \mathrm{mg}$ ), and the lowest Sodium amount value was determined in Pehlivan variety in early drought application (K1: $0.20 \mathrm{mg}$ ). In terms of the Sodium $(\mathrm{Na})$ in the stem tissues of the wheat plants, when the average values were examined, it was determined that the highest Sodium amount was in Ceyhan-99 variety $(15.41 \mathrm{mg})$ and the lowest Sodium amount was in Pehlivan variety (0.69 mg). In terms of drought levels, the highest Sodium amount average was determined in full drought application (K3: $18.90 \mathrm{mg})$, and the lowest Sodium average was determined in early drought application (K1: $3.35 \mathrm{mg})$. In terms of variety-drought interaction, the highest Sodium amount was determined in Ceyhan-99 variety in irrigated conditions application (K0: $27.05 \mathrm{mg}$ ), and the lowest Sodium amount value was determined in Pehlivan variety in full drought application (K3: $0.21 \mathrm{mg}$ ) (Table 8).

Table 8. The average values of Sodium amounts in the plant roots and stems

\begin{tabular}{c|c|c|c|c|c|c|c|c|c|c}
\hline \multicolumn{10}{c|}{ K0 } & \multicolumn{2}{c}{ K1 } & \multicolumn{2}{c}{ K2 } & \multicolumn{2}{c}{ K3 } & \multicolumn{3}{c}{ Average } \\
\hline & \multicolumn{2}{|c|}{ Kodium (Na) } \\
\hline Cultivars & Root & Stem & Root & Stem & Root & Stem & Root & Stem & Root & Stem \\
\hline Ceyhan-99 & 27.05 & 18.61 & 4.90 & 23.34 & 2.89 & 0.14 & 26.81 & 13.05 & 15.41 & 18.33 \\
Pehlivan & 0.81 & 0.71 & 0.92 & 0.20 & 0.83 & 2.22 & 0.21 & 0.42 & 0.69 & 2.22 \\
Firat-93 & 18.73 & 20.42 & 4.04 & 2.59 & 8.49 & 9.10 & 17.54 & 16.54 & 12.20 & 12.16 \\
Sarıçanak-98 & 4.17 & 4.51 & 1.11 & 1.39 & 17.88 & 0.83 & 12.41 & 1.01 & 8.89 & 2.30 \\
\hline Average & 16.65 & 14.51 & 3.35 & 9.11 & 9.76 & 9.10 & 18.90 & 10.20 & & \\
\hline
\end{tabular}

\section{Conclusion}

The effects of drought on the development and yield of the wheat depends on the developmental period in which drought occurs, on the severity, and on the time of the drought. The negative effect of drought on the leaf area after the heading and blooming is considered as the sole reason of the decrease in the yield. The drought occurring at the spike formation stage causes reductions in the number of grains in spike, and the one occurring after the blooming affects negatively the increase in the mass weight of the grains after a certain point.

The increase of Potassium concentration in plant tissues increases the durability of the plant to stress factors (Hsiao and Lauchli, 1986). It is known that the genotypes which have more $\mathrm{K}$ and $\mathrm{Ca}$ ions in green parts and roots have increased endurance to stress conditions, and in addition, this also causes increases in the enzyme activities in the genotypes during drought stress (Kusvuran, 2010). One of the basic elements that is necessary for growth and development is $\mathrm{K}$ and the other one is $\mathrm{Ca}$ ion. Abiotic stress affects the $\mathrm{K}$ and $\mathrm{Ca}$ intake negatively. In the present study, it was observed that 
drought stress increased the $\mathrm{K}$ and $\mathrm{Ca}$ levels in the plant however, it was also observed that this level changed according to different drought applications. It is possible to claim that especially in the late drought application, the substance coverage of both minerals increased. Again, it was also determined that the cultivars showed different $\mathrm{K}$ and $\mathrm{Ca}$ levels in different drought applications. It is known that the Sodium ion causes necrotic stains on the shoots and leaves starting from the old leaves in drought conditions (Aktas, 2002; Dasgan et al., 2006). As seen in the $\mathrm{K} / \mathrm{Na}$ and $\mathrm{Ca} / \mathrm{Na}$ rates in the green parts and roots, it was determined that the genotypes with higher $\mathrm{Na}$ and lower $\mathrm{K}$ and $\mathrm{Ca}$ contents were more susceptible to damage.

As a result, Ceyhan-99 cultivar which show the best average of 7 agricultural and biochemical characters, were superior to all other wheat cultivars in Southeast Anatolia conditions of Turkey. However, these drought studies should be continued for longer years and changing climate conditions, the drought resistance of the varieties, produced in the region should be determined.

Acknowledgements. This research was supported by a grant from Dicle University Research Funding (DUBAP; Project No. ZIRAAT.17.001).

\section{REFERENCES}

[1] Aghanejad, A., Jalilian, A. R., Ardaneh, K., Bolourinovin, F., Yousefnia, H., Samani, A. B. (2015): Preparation and quality control of (68) Ga-Citrate for pet applications. - Asia Ocean J Nuci Med. Biol. 3(2): 99-106.

[2] Aktas, H. (2002): Physiological characterization and inheritance of salt tolerance in pepper. - Cukurova University, Institute of Science. PhD Thesis. Adana, 105 page.

[3] Cook, R. J., Veseth, R. J. (1991): Wheat health management. - The American Phytopathological Soc. 3340 Pilot Knob Road, St, Paul, Minnesota 55121, USA.

[4] Dasgan, H. Y., Koc, S., Ekici, B. (2006): The Responses of Some the bean and Cowpea Cultivars to Salt Stress. - Turkish Journal of Alatarim 5(1): 23-31.

[5] Hsiao, T. C., Lauchli, A. (1986): Role of Potassium in plant-water relations. - In Advences in plant Nutrition 2: 281-312. Preager Scientific, New York.

[6] Kalefetoglu, T., Ekmekci, Y. (2005): The effects on drought on plants and tolerance mechanisms. Gazi University Journal of Science 18: 723-740.

[7] Kusvuran, S. (2010): Relationships between physiological mechanisms of tolerances to drought and salinityin melons. - Department of Horticulture, Institute of Natural and Applied Sciences University of Cukurova. PhD Thesis.

[8] Monti, L. M. (1986): Breeding Plants for Drought Resistance: The Problem and its Relevance. - Drought Resistance in Plants. Meeting Held in Amalfi. 19 to 23 October 1986. Belgium, 1-8.

[9] Reynolds, M. P., Rajaram, S., Sayre, K. D. (1999): Physiological and genetic changes of irrigated wheat in the post-green revolution period and approaches for meeting projected global demand. - Crop Science 39: 1611-1621.

[10] Richards, R. A., Rebetzke, G. J., Watt, M., Condon, A. G., Spielmeyer, W., Dolferus, R. (2010): Breeding for improved water productivity in temperate cereals: phenotyping, quantitative trait loci, markers and the selection environment. - Functional Plant Biology 37: 85-97.

[11] Zadoks, J. C., Chang, T. T., Konzak, C. F. (1974): A demical code for growth stage of creals. - Weed. Res. 14: 415-421. 